\title{
AS INTERAÇÕES ENTRE A CONVENÇÃO SOBRE A DIVERSIDADE BIOLÓGICA (CDB) E O TRIPS ${ }^{1}$
}

INTERACTIONS BETWEEN THE BIOLOGICAL DIVERSITY CONVENTION AND THE TRIPS

Vladimir Garcia Magalhães ${ }^{2}$

\begin{abstract}
Resumo:
A biodiversidade é fonte de recursos para a pesquisa em biotecnologia e indústria biotecnológica, tendo por isso grande valor econômico. A CDB determina que os benefícios resultantes do uso comercial e científico dos recursos genéticos existentes na biodiversidade devem ser repartidos por quem os usa com os países que os provêm. $\mathrm{O}$ texto do TRIPS deve ser revisto e alterado para se harmonizar com a CDB e garantir o cumprimento dos seus objetivos.

Palavras-chave: Biodiversidade. Biotecnologia. Convenção sobre a diversidade biológica. CDB. Patentes. TRIPS.
\end{abstract}

\begin{abstract}
:
Biodiversity is source of resources to biotechnology an biotechnologic industry. the Biologic Diversity Convention states that the benefits gained by commercial and scientific uses of the genetic resources in the biodiversity must be shared by those who use with the countries that provide it. The text of the TRIPS must be reviewed and changed to harmonize with BDC and assure the achivement of its goals.
\end{abstract}

Keywords: Biodiversity. Biotechnology. Biologic Diversity Convention (BDC). Patent.

\section{Introdução}

Ao longo da evolução, o ser humano diferenciou-se dos demais animais pela sua capacidade inventiva, ou seja, de desenvolver instrumentos com os recursos disponíveis em seu meio ambiente, que o ajudasse a sobreviver neste mesmo meio ambiente.

Com a evolução da sociedade humana, estes processos e produtos da capacidade inventiva humana passaram a ser tutelados pelo Direito, constituindo-se a propriedade intelectual.

\footnotetext{
Em homenagem à memória do saudoso mestre e Prof. Guido Fernando Silva Soares, que iluminou com seus conhecimentos, inteligência e dedicação docente, tantos caminhos acadêmicos, mostrando aos seus alunos quão fascinante pode ser o Direito Internacional Ambiental.

2 Advogado e biólogo. Mestre e Doutor em Direito Civil pela Faculdade de Direito da Universidade de São Paulo
} 
Se, por um lado, a capacidade inventiva humana foi crucial para a sobrevivência da espécie, por outro lado, trouxe como conseqüência o uso indiscriminado dos recursos ambientais e o desequilíbrio ecológico do meio ambiente.

Contudo, esta mesma capacidade racional, permitiu aos seres humanos entenderem, cientificamente, seu meio ambiente e que o desequilíbrio ecológico ameaçaria a sua própria existência, ficando evidente, portanto, a importância da preservação ambiental.

O meio ambiente e também os processos e produtos resultantes da capacidade inventiva humana, foram tutelados inicialmente pelas leis nacionais, mas passaram, ao longo do tempo, a ser também protegidos por acordos, tratados, convenções e outras formas contratuais entre Estados, que constituem o Direito Internacional Público.

$\mathrm{Na}$ área de propriedade intelectual um desses diplomas é o Trade Related Intelectuall Property Rights (TRIPS). Na área ambiental, temos, entre outros, a Convenção da Diversidade Biológica (CDB).

O TRIPS trata da proteção da propriedade intelectual, abrangendo, portanto, a propriedade intelectual sobre a biotecnologia e seus produtos. A CDB trata da proteção da biodiversidade e da repartição dos benefícios, econômicos e científicos, entre os países que a detém e os países que a utilizam.

Neste trabalho, analisaremos a interação entre o TRIPS e a CDB que ocorre pelo uso da biodiversidade pela biotecnologia e pela indústria biotecnológica, assim como os conflitos e convergências que esses diplomas internacionais apresentam entre si.

Procuraremos com isso apontar sugestões de alteração do conteúdo do TRIPS para que este se harmonize ao máximo com a CDB, de modo a proteger os direitos de propriedade intelectual relativos aos conhecimentos das comunidades tradicionais associados à biodiversidade e, também, proteger os interesses nacionais dos Estados fornecedores dos recursos biológicos constituintes da biodiversidade.

Esta harmonização é imprescindível para que o Direito de Propriedade Intelectual, no âmbito do Direito Internacional Público, não se constitua em mais um instrumento de expropriação, pelos Estados mais desenvolvidos do chamado Primeiro Mundo, das riquezas naturais e culturais dos Estados menos desenvolvidos, perpetuando a gigantesca desigualdade social e econômica existente entre eles. 


\section{O Conceito de Biodiversidade}

A palavra biodiversidade apareceu há relativamente pouco tempo. Tornouse conhecida a partir de uma reunião realizada nos EUA, cujos trabalhos foram publicados, em 1988, em um livro organizado pelo ecólogo Edward O. Wilson, da Universidade de Harvard, também nos Estados Unidos.

Existem pelo menos dois conceitos de biodiversidade elaborados por profissionais da área biológica:

A soma de todos os diferentes tipos de organismos que habitam uma região tal como o planeta inteiro, o continente africano, a Bacia Amazônica, ou nossos quintais. (Andy Dobson) ${ }^{3}$

Toda a variação baseada em hereditariedade em todos os níveis de organização, dos genes existentes em uma simples população local ou espécies, as espécies que compõem toda ou parte de uma comunidade local, e finalmente, as próprias comunidades que compõem a parte viva dos multivariados ecossistemas existentes no mundo (Edward O. Wilson $\left.{ }^{4}\right)$.

Todas as definições - estas e muitas outras - enfatizam que a biodiversidade abrange diferentes níveis de organização da vida. Tais níveis formam uma certa hierarquia: os genes que pertencem a organismos que compõem populações que pertencem a espécies cujos conjuntos formam comunidades que fazem parte dos ecossistemas.

A Convenção da Diversidade Biológica (CDB), apresentada na reunião das Nações Unidas sobre o Meio Ambiente (Eco-92), realizada no Rio de Janeiro, em 1992, define a biodiversidade, pelo seu sinônimo diversidade biológica, do seguinte modo:

Diversidade biológica significa a variabilidade de organismos vivos de todas as origens, compreendendo, dentre outros, os ecossistemas terrestres, marinhos e outros ecossistemas aquáticos e os complexos ecológicos de que fazem parte; compreendendo ainda a diversidade dentro de espécies, entre espécies e de ecossistemas. (CDB, Artigo $2^{\circ}$ ). (grifamos). ${ }^{5}$

Para fins deste trabalho adotaremos o conceito enunciado no art. $2^{\circ}$ da CDB.

3 DOBSON, Andrew P. Conservation and biodiversity. New York: Scientific American Library, 1996. p. 132.

4 REAKA-KUDLA, Marjorie L.; WILSON, Don E.; WILSON, Edward O. (Eds.). Biodiversity II: understanding and protecting our biological resources.Washington, D.C.: Joseph Henry Press, 1997. p. 1.

5 No original: "the variability amoung living organisms from all sources including, inter alia, terrestrial, marine and other aquatic ecosystems and the ecological complexes of wich they are part; this includes diversity within species, between species and of ecosystems". 


\section{O Conceito de Biotecnologia}

É necessário também definir o que é exatamente a tecnologia conhecida pelo nome de biotecnologia. Os dicionários ainda não conceituam, com exatidão, esta palavra. Biotecno tem relação com biotecnia, a qual é definida como sendo a "arte de utilizar os animais e vegetais para obter deles o maior proveito possível'. ${ }^{6}$

A Organização Mundial da Propriedade Intelectual (OMPI) afirma que a biotecnologia tem sido descrita como sendo uma técnica que usa os organismos vivos (ou parte dos organismos), para fabricar ou modificar produtos, para aperfeiçoar plantas e animais ou ainda desenvolver microorganismos para usos específicos. ${ }^{7}$

Assim podemos definir a biotecnologia como sendo o conjunto de técnicas que efetivamente alteram os seres vivos, como são encontrados ao longo de sua evolução natural, para atender as necessidades humanas, notadamente as de caráter econômico.

A fermentação da uva para obtenção de vinho, pelo levedo Saccharomyces cerevisae, é um exemplo de biotecnologia tradicional, já conhecida pela sociedade humana há milhares de anos.

O melhoramento genético das espécies vegetais e animais por intermédio de cruzamentos cuidadosamente programados e efetivados pelo ser humano é outro exemplo de biotecnologia.

No decorrer do desenvolvimento da biotecnologia, surgiram técnicas de manipulação dos genes existentes nos animais, plantas e microorganismos, integrantes dos diversos ecossistemas, chamadas de engenharia genética.

Em 1944, Oswald Avery, Colin MacLeod e Maclyn MacCarty, publicaram a sua descoberta de que um acido nucléico, denominado de Ácido Desoxirribonucléico (DNA), seria responsável pela transmissão de certas características de membrana celular da bactéria pneumococo relacionadas à patogenicidade desta bactéria. Essa descoberta foi considerada um marco no desenvolvimento da bioquímica e, logo a seguir, foi desvendada a composição química do DNA. Sabia-se já naquele momento, também, que os genes dos animais e plantas eram constituídos de moléculas de DNA. ${ }^{8}$

Finalmente, em 1953, James Watson e Francis Crick deduziram a estrutura tridimensional helicoidal em dupla hélice do DNA e seus mecanismos de multiplicação

\footnotetext{
6 SOARES, José Carlos Tinoco. Biotecnologia: a mais avançada tecnologia da vida. Revista da ABPI, Rio de Janeiro, n. 10, p. 38-40, jan./fev. 1994.

7 Id. Ibid.

8 STRYER, Lubert. Bioquímica. Rio de Janeiro: Editora Reverté, 1979. p.560.
} 
dentro das células. Tal descoberta brilhante foi uma das mais significativas da história da Biologia, pois permitiu compreender a função do gene em termos moleculares. ${ }^{9}$

Estavam assentadas as bases da moderna biotecnologia, ou seja, da manipulação pelo ser humano do DNA que constitui os genes existentes nos organismos.

O gene pode ser definido como sendo a menor unidade de informação do organismo. O conjunto de genes de um ser vivo vai constituir o seu genoma. Cada espécie tem um genoma característico, que define as suas características morfológicas e fisiológicas, ou seja, relativas à sua forma física e o modo que este organismo vai funcionar biologicamente.

Cada gene vai ser responsável pela produção de uma proteína, sendo que o conjunto destas proteínas em cada organismo é que vai possibilitar o seu desenvolvimento e funcionamento biológico, a partir de sua gênese, até o final do seu ciclo de vida.

As proteínas irão desempenhar inúmeras funções nos organismos vivos, como a produção e armazenamento de energia para o funcionamento do ser vivo, até a constituição de importantes tecidos dos organismos como os músculos, o tecido nervoso nos animais superiores, etc. ${ }^{10}$

Com o desenvolvimento da engenharia genética, como área da biotecnologia, e sua capacidade para identificar e manipular os genes, transferindo, inclusive eles, de um organismo de uma espécie para outra, como de um animal para uma bactéria, estes genes passaram a ser patenteados em diversos países, notadamente os mais desenvolvidos, tanto em sua forma manipulada, resultado da invenção humana, quanto em sua forma natural, ou seja, como são encontrados nos seres vivos.

Assim, a engenharia genética aumentou o valor da biodiversidade, e dos recursos genéticos nela existentes, como fonte de matéria-prima para a biotecnologia e seus produtos, passando a ter valor incalculável do ponto de vista científico e econômico.

\section{O Uso Econômico da Biodiversidade e a Biotecnologia}

$\mathrm{O}$ impacto econômico da engenharia genética é gigantesco e tende a crescer à medida que ela se desenvolva mais e se descubram nos organismos vivos que constituem a biodiversidade, genes capazes de produzir novas substâncias para a indústria farmacêutica e outras indústrias, ou ainda capazes de aperfeiçoar os animais e plantas

\footnotetext{
9 STRYER, Lubert. Bioquímica. Rio de Janeiro: Editora Reverté, 1979. p. 563-564.

${ }^{10}$ Id. Ibid., passim.
} 
utilizados pelo homem na agricultura, de modo a aumentar a produtividade e, portanto, os lucros da atividade agrária.

Nos EUA, avalia-se que $25 \%$ das receitas obtidas com medicamentos correspondem a medicamentos, cujos princípios ativos são extraídos de plantas. Somente em 1990, em valores absolutos, este valor correspondeu à quantia de 15 bilhões de dólares. ${ }^{11}$

Descoberto inicialmente em um microorganismo de solo do Japão, um medicamento veterinário, utilizado para combater parasitas, rendeu à Merck, em vendas, o valor de 100 milhões de dólares, em 1991. ${ }^{12}$

A comunidade científica mundial espera encontrar, nos animais, plantas e microorganismos que compõe a biodiversidade, remédios eficazes contra doenças de extrema gravidade, patológica e social, como o câncer e a AIDS.

O Instituto Nacional do Câncer, nos EUA, está pesquisando 10 mil substâncias, de origem biológica, para tentar isolar algumas que sejam eficazes contra 100 tipos de células cancerosas e o vírus HIV. ${ }^{13}$

O número de empresas farmacêuticas atuando nos países em desenvolvimento detentores de maior biodiversidade, em projetos de coleta de componentes da biodiversidade (bioprospecção), como recursos genéticos (DNA e RNA em retrovírus) e outras moléculas biológicas, para isolamento de substâncias comerciais, era avaliado em 21, até 1993.14

As empresas fazem a bioprospecção utilizando o conhecimentos das populações tradicionais pertencentes aos locais de coleta, que conhecem profundamente a biodiversidade local e seus usos para os seres humanos. Se a coleta for feita sem estes conhecimentos, estima-se que seja necessário isolar 10 mil produtos químicos, de origem biológica, para se obter um que tenha potencial para uso comercial. ${ }^{15}$

Assim, podemos constatar que - com o progresso das modernas áreas da biotecnologia, como a engenharia genética -, os recursos genéticos do planeta e as moléculas biológicas produzidas pelos organismos, a partir deles, tornaram-se extremamente estratégicos, do ponto de vista econômico e político.

\footnotetext{
11 Peter Principe apud REID, W. et al. Prospección da la Biodiversidad, p. 8.

12 COUGHLIN JUNIOR, Micahel D. -- Using the Merk-INBio agreement to clarify the convention on biological diversity. Columbia Journal of Transnationl Law, New York, v. 31, n.2. p. 337-375, 1993.

${ }^{13}$ REID, Walter. et al. op. cit., p. 357.

14 Id. Ibid., p.8-15.

15 Id. Ibid.
} 
Conseqüentemente, uma legislação de patentes, ambiental e socialmente corretas, deve levar isso em conta, tanto nos diplomas internacionais relativos à esta matéria, como o TRIPS e a CBD, quanto nas legislações nacionais dos países que detêm esta biodiversidade.

Como conseqüência da percepção, pelas empresas dos países desenvolvidos e seus governos, do potencial econômico desta biodiversidade, surgem interesses conflitantes entre esses países e suas empresas, que utilizam estes recursos genéticos, e os países que fornecem estes componentes de sua biodiversidade.

Os EUA, por exemplo, infelizmente, já têm certa notoriedade, no sentido de patentear organismos e genes oriundos de países em desenvolvimento. Há alguns anos atrás, houve naquele país a concessão de patente número 5.397.696, para o Instituto Nacional de Saúde explorar comercialmente uma linhagem de retrovírus HTVL-1, descoberto em um indígena hagaihai, na Papua-Nova Guiné. ${ }^{16}$

Estima-se que, em 1998, a indústria de bioprodutos (produtos resultantes de seres vivos) tenha vendido mais de 13 bilhões de dólares e aprovado 24 novas biodrogas, o que significa um altíssimo retorno aos investidores.

Logo, os recursos genéticos provenientes dos animais, plantas e microorganismos, existentes nos ecossistemas, e os genes humanos têm grande valor econômico. Estes genes, mesmo aqueles com funções biológicas ainda desconhecidas, têm sido patenteados nos EUA e União Européia. ${ }^{17}$

Em 1990, por iniciativa do Governo norte-americano, iniciou-se nos EUA o Projeto Genoma Humano, que pretende desvendar toda a seqüência de nucleotídeos do genoma humano. ${ }^{18} \mathrm{Um}$ dos maiores benefícios que este projeto pode trazer é a terapia genética, que consiste na introdução de genes normais nas células que portam genes anormais que causam determinada doença, com a finalidade de corrigir este gene.

Estudos neste sentido têm resultado em novos tratamentos para câncer de mama, ovário e de próstata. O potencial uso dessa tecnologia para tratamento de doenças até agora incuráveis, ou de difícil tratamento, é dificilmente comensurável.

A relevância comercial dessa terapia surge da possibilidade de desenvolvimento de uma nova geração de remédios, baseados em genes, que terão menos

\footnotetext{
${ }^{16}$ SILVA, Carlos E. da. EUA patenteiam vírus de índio e são acusados de pirataria. Folha de S. Paulo, 16 de junho de 1996, p. 13.

17 Id. Ibid., p. 23.

18 RAYOL, Alice. Biotecnologia, ética e patentes. Revista da ABPI, Rio de Janeiro, n. 44, p. 20-4, jan./fev. 2000.
} 
efeitos colaterais e que prometem revolucionar o mercado. A venda desses novos remédios traduz-se em um lucro fantástico para as empresas que dominarem essa tecnologia e detiverem os direitos de propriedade sobre ela na forma de patentes.

Em função das descobertas resultantes do Projeto Genoma Humano, iniciouse, nos EUA, uma corrida às patentes das seqüências de nucleotídeos dos genes humanos em seu estado natural, ou seja, os próprios genes foram patenteados. ${ }^{19}$ Espera-se que esta prática resulte em um aumento da desigualdade entre as nações ricas e pobres e também a desigualdade entre ricos e pobres no interior de cada nação. ${ }^{20}$

A concessão de patentes para genes naturais existentes nos seres humanos e outros organismos revela que este instituto está sendo alterado profundamente e que há uma tendência para eliminar qualquer distinção entre invenção e descoberta, ${ }^{21}$ o que contraria todo o direito de propriedade intelectual, desde as suas origens, para atender o interesse casuístico das empresas dos países desenvolvidos em obter monopólio sobre o uso destas moléculas encontradas na natureza e, com isso, aumentar seus lucros o máximo possível.

Entre 1981 e 1995, foram concedidas, em todo o mundo, 1.175 patentes para seqüências de DNA humano. Nos EUA, por meio de uma série, de decisões que partem do Caso Amgen e culminam com o Caso Deuel, firmou-se uma corrente jurisprudencial favorável ao patenteamento irrestrito das sequências de DNA por meio da simplificação ou eliminação de requisitos objetivos da patenteabilidade, ${ }^{22}$ como a inventividade.

Esta deformação do direito de patentes para atender os interesses das empresas dos países desenvolvidos, que surgiram com os progressos da Biologia molecular e Engenharia genética, resultou não-somente na possibilidade de se patentear genes naturais mas, também, organismos vivos como um todo.

Isto começou a ocorrer nos EUA, em 12 de abril de 1988, quando o Escritório de Patentes dos EUA concedeu uma patente, sob o n. 4.736.866, sobre um rato transgênico, ou seja, com seu genoma alterado pela Engenharia genética. Esta foi a primeira patente concedida para um animal transgênico no mundo, ${ }^{23}$ mas não foi a última.

\footnotetext{
${ }^{19}$ BERLINGER, Giovanni. Ciência, mercado e patentes do DNA humano. Bioética, Brasília, v. 8, n. 1, p. 98-9, 2000.

${ }^{20}$ Id. Ibid., p. 99.

${ }^{21}$ Id. Ibid., p. 100.

${ }^{22}$ BERGEL, Salvador D. Patente de genes: implicâncias éticas e jurídicas. Bioética, Rio de Janeiro, v. 5, n. 2, p. 245. 1997.

${ }^{23}$ SOARES, José Carlos Tinoco. op. cit., p. 39.
} 
5. A propriedade intelectual e as patentes

A propriedade intelectual em sentido amplo significa os direitos resultantes da atividade intelectual nos campos industrial, científico e literário. Os países têm leis para proteger a propriedade intelectual basicamente por duas razões.

Primeira, a de proteger legalmente o direito moral e econômico dos criadores sobre as suas criações e o direito do público de acesso à estas criações, e a segunda, é a de promover, como política governamental, a criatividade e a disseminação e aplicação dos seus resultados, assim como estimular um justo comércio que contribuiria para o desenvolvimento econômico e social.

AConvenção que criou a Organização Mundial sobre a Propriedade industrial (OMPI), em seu art. 2.VIII, diz que a propriedade intelectual inclui os direitos relativos a trabalhos literários, artísticos, científicos, perfomances de artistas, discos, programas de rádios, invenções em todas as áreas do conhecimento humano, descobertas científicas, desenhos industriais, marcas, nomes e designações comerciais e todos os outros direitos resultantes da atividade intelectual na área industrial, científica ou ainda artística.

As produções literária, artística e científica, correspondem aos direitos autorais. As áreas de performances artísticas, discos, e programas de rádio são usualmente chamadas de direitos conexos aos direitos autorais.

As invenções, desenhos industriais, marcas e nomes comerciais constituem a propriedade industrial como ramo da propriedade intelectual. De modo simplificado, invenções podem ser definidas como soluções novas para problemas técnicos, podendo ser um produto ou um processo. Os desenhos industriais são criações estéticas que determinam a aparência de produtos industriais.

A patente é um documento publicado pelo Governo, mediante solicitação do interessado, que descreve uma invenção e cria uma situação legal, através da qual a invenção patenteada pode ser normalmente explorada (produzida, utilizada e vendida), com a autorização do proprietário da patente.

A proteção concedida pela patente é limitada no tempo, em geral no máximo 20 anos, e os requisitos clássicos para a concessão de patente são a novidade, a existência de atividade inventiva para se obter aquele produto e a utilidade industrial.

6. A OMPI, o TRIPS, a CDB e suas interações

Durante o século XIX, antes da existência de convenções internacionais na área da propriedade industrial era muito difícil obter proteção para os direitos de 
propriedade industrial em vários países do mundo, devido a diversidade das suas leis. Deste modo, as patentes tinham que ser registradas ao mesmo tempo em todos os países para se evitar que a publicação em um país destruísse a novidade da invenção nos demais países.

Em decorrência disso, em 1883, foi aprovada a Convenção de Paris para a Proteção da Propriedade Industrial que foi assinada por 11 Estados: Bélgica, Brasil, Salvador, França, Guatemala, Itália, Holanda, Portugal, Sérvia, Espanha e Suíça. Em 1884, Grã-Bretanha, Tunísia e Equador aderiram, elevando para 14 o número de membros desta convenção, sendo que somente no início do século XX é que este número aumentou significativamente.

Em 1886, foi assinada a Convenção de Berna para a Proteção de Trabalhos Artísticos e Literários. Esta convenção foi revisada a cada 20 anos, aproximadamente, até ocorrerem as revisões de Estocolmo, em 1961, e a de Paris, em 1971.

As conferências de revisão eram convocadas, em geral, para encontrar respostas aos novos desenvolvimentos tecnológicos, como a gravação de sons, fotografia, rádio, cinematografia e televisão.

Nas décadas de 70 e 80, do século passado, uma série de novas tecnologias foram desenvolvidas como a reprografia, videotecnologia, sistemas de cassetes compactos que permitiam as gravações caseiras, rede de satélites para transmissão de programas de rádio e TV pelo mundo, TV a cabo, desenvolvimento de programas de computador e disseminação de seu uso em todos os países.

Deve-se salientar que descobertas científicas não são o mesmo que invenções. O Tratado de Genebra sobre o Registro de Descobertas Científicas, de 1978, define em seu art. $1^{\circ}$, descoberta científica como sendo "o reconhecimento de fenômenos, propriedades ou leis do universo material, até então desconhecidos e passíveis de serem verificados", enquanto invenções são novas soluções para problemas técnicos específicos.

As Convenções de Paris e de Berna, de 1883 e 1886, respectivamente, estabeleceram, cada uma, secretariados internacionais para a sua administração, que se localizaram em Berna, na Suíça. Inicialmente eram dois secretariados, um para a propriedade industrial e outro para direitos autorais para as duas convenções. Em 1893, os dois secretariados foram reunidos e passaram a ter diversos nomes sucessivamente.

Após adotar o nome de BIRPI, sigla em francês para United International Bureaux for the Protection of Intellectual Property, em 1960, o secretariado mudou-se de Berna para Genebra. 
Em 1970, durante a Conferência de Estocolmo, foi criada a OMPI(WIPO em inglês) a partir da BIRPI, após a revisão de todos os tratados por ela administrados. A seguir, a OMPI (WIPO) tornou-se, em 17 de dezembro de 1974, por um acordo com as Nações Unidas, uma agência especializada do seu sistema de organizações intergovernamentais.

O Acordo Geral de Tarifas e Comércio ( GATT- General Agreement on Tariffs and Trade) foi firmado em 1947. A Rodada do Uruguai, de negociações multilaterais deste tratado, foi concluida em 15 de dezembro de 1993. O Acordo da OMC, resultante daquelas negociações, foi adotado em 15 de abril de 1994, em Marrakesh, e criou a Organização Mundial do Comércio (OMC).

As negociações da Rodada do Uruguai, incluíram pela primeira vez no GATT, ou seja, no âmbito do comércio internacional, questões relacionadas à propriedade intelectual. O resultado dessas negociações, contido no Anexo do Acordo da OMC, foi o TRIPS - Agreement on Trade-Related Aspects of Intellectual Property Rights.

O Acordo da OMC, incluindo nele o Acordo do TRIPS entraram em vigor em 01 de janeiro de 1955. Aos membros destes acordos foi dado um certo período de tempo após esta data, antes de serem obrigados a aplicar o Acordo TRIPS em seus territórios, para que pudessem adequar suas lei internas ao mesmo.

O TRIPS determina aos países-membros desenvolvidos para fornecer, quando requerido e em condições e termos acordados, cooperação técnica e financeira em favor dos países-membros em desenvolvimento e menos desenvolvidos, incluindo assistência para elaboração de leis e apoio para criação ou incremento de agências ou órgãos relacionados à concessão de patentes, incluindo-se aí o treinamento de pessoal especializado (art. 67).

A OMC, foi organizada numa estrutura de três níveis. A mais elevada é a Conferência Ministerial, que se reúne pelo menos a cada 2 anos (art. IV.1). Ela tem a autoridade para tomar decisões em todas as matérias de competência da OMC. A segunda é o Conselho Geral, constituído por todos os membros, que se encontram quando for necessário para conduzir as suas tarefas e as da Conferência Ministerial, nos intervalos entre os encontros desta última (art. IV.2).

O Acordo da OMC também estabelece um Conselho para Aspectos Relacionados ao Comércio dos Direitos de Propriedade Intelectual, o chamado "Conselho do TRIPS", o qual sob a direção do Conselho Geral, supervisiona o funcionamento do TRIPS (art. IV.5).

A associação no Conselho do TRIPS é aberta aos representantes de todos os países. Sob as determinações do Acordo TRIPS, o Conselho é responsável por monitorar 
as operações do TRIPS e o cumprimento, pelos membros, das obrigações assumidas com o acordo. O primeiro encontro do Conselho do TRIPS ocorreu em 09 de março de 1995.

O Acordo TRIPS determina o estabelecimento de preparativos para cooperação e apoio mútuo entre a OMC e OMPI, relativos à propriedade intelectual, atribuindo que o Conselho, no exercício de suas funções, poderia consultar e procurar informações de quaisquer fontes que considere apropriada e que, consultando a OMPI, o Conselho deveria estabelecer, após um ano do seu primeiro encontro, preparativos adequados para a cooperação com órgãos da OMPI (art. 68).

Consultas e conferências para áreas específicas de cooperação entre a OMPI e OMC também são exigidas pelo TRIPS, em particular, devido ao art. 63.2, relativo às notificações de leis e regulamentos por membros ao Conselho do TRIPS.

Os membros do TRIPS são livres para determinar o método apropriado para implementar as obrigações assumidas no seu próprio sistema legal e pode dar uma proteção mais extensiva e abrangente à propriedade intelectual, que aquela exigida pelo TRIPS aos seus membros, desde que esta proteção adicional não conflite com outras cláusulas do acordo (art. 1.1 e 1.3).

O TRIPS estabelece que, para as propostas do acordo o termo "propriedade intelectual" se refere a todas as categorias de propriedade intelectual, que são objeto da Seção 1 a 7 da Parte II do TRIPS, particularmente, direitos autorais e conexos, marcas de comércio, indicações geográficas, desenhos industriais, patentes e desenhos topográficos de circuitos integrados (art. 1.2).

O TRIPS baseia-se em princípios incorporados da Convenção de Paris para a Proteção da Propriedade Industrial e da Convenção de Berna para a Proteção de Trabalhos Literários e Artísticos. Em relação à propriedade industrial, o TRIPS exige que seus membros cumpram os arts. do $1^{\circ}$ ao 12 e art. 19 da Convenção de Paris e os arts. $1^{\circ}$ ao 21, da Convenção de Berna. ${ }^{24}$

$\mathrm{O}$ art. 27 do TRIPS trata da patente e seus requisitos. Determina que são passíveis de patente qualquer invenção, seja produto, seja processo, em todos os campos da tecnologia, desde que sejam novos, tenham uma etapa inventiva e sejam passíveis de utilização industrial.

Além disso, este artigo permite que, em alguns casos nele elencados, os países-membros excluam de patenteabilidade algumas invenções, como o caso da exclusão para proteger a ordem pública e também o meio ambiente.

${ }^{24}$ Organização Mundial da Propriedade Intelectual, Intellectual Property Handbook: Policy, Law and Use. Disponível em: <http.wipo.int/about-ip/en/iprm>. 
O Acordo Norte-Americano (ALENA), firmado entre EUA, Canadá e Mexico, por sinal, também prevê a possibilidade de que os Estados-membros, excluam a patenteabilidade de invenções, quando lhes parecer necessário impedir sua exploração comercial para proteger o meio ambiente, de modo semelhante ao determinado no TRIPS em seu art. 27.2.25

Finalmente, cabe destacar que o TRIPS é extremamente flexível, pois prevê a possibilidade de revisão do seu texto depois de 6 anos de sua entrada em vigor e, a partir disto, a cada dois anos (art. 71). Isto é positivo, se pensarmos na hipótese de sua alteração para se harmonizar com a CDB.

A Convenção da Diversidade Biológica (CDB), por sua vez, surgiu em decorrência do intenso debate que foi se formando em relação ao meio ambiente e sua proteção, notadamente a partir da década de 60, assim como a sua crescente importância política, legal e econômica. ${ }^{26}$

O desenvolvimento industrial global, especialmente nos países mais desenvolvidos economicamente, a expansão das atividades econômicas das empresas desses países nas regiões menos desenvolvidas do globo e com meio ambiente mais preservado, como conseqüência da globalização, foram fatores determinantes para o aumento da escalada da destruição de vários ecossistemas muito importantes e expressivos no planeta, como as florestas tropicais.

Paralelamente, o desenvolvimento científico de áreas como a ecologia, permitiram entender e valorar melhor o significado destes ecossistemas e formular conceitos como o da biodiversidade referente a variabilidade de seres vivos existentes em determinado espaço geográfico.

Essa constante preocupação internacional em relação ao meio ambiente veio a ser formalizada durante a Conferência das Nações Unidas sobre o Meio Ambiente Humano, realizada em Estocolmo, entre 5 e 16 de junho de 1972. ${ }^{27}$

Essa conferência elaborou um Plano de Ações para o Meio Ambiente, que reorganizou todas as recomendações aprovadas pela Conferência, e uma Declaração sobre o Meio Ambiente Humano, que estabeleceu princípios gerais que embasaram a elaboração

\footnotetext{
${ }^{25}$ WOLFF, Maria Teresa. Proteção do Meio Ambiente. Revista da ABPI, Rio de Janeiro, n. 16, p. 30-3, maio/jun. 1995.

26 SILVA, Eugênio Costa e. Breves Considerações sobre o acesso a recursos genéticos e alguns assuntos correlatos. Revista da ABPI, Rio de Janeiro, n. 28, p. 40-52, maio/jun. 1997.

${ }^{27}$ Id. Ibid., p. 41.
} 
de acordos internacionais para a proteção do meio ambiente e a criação de um sistema institucional para coordenar ações e políticas conjuntas dos países nesse sentido. ${ }^{28}$

Uma resolução da ONU, nesse mesmo ano de 1972, sugeriu o estabelecimento de um programa, dentro do sistema institucional da própria ONU, que coordenaria todas as atividades ambientais nos âmbitos nacional e internacional, assim como o desenvolvimento de instrumentos legais internacionais e leis modelos para serem adotadas pelos países, com o fim de implementar o Plano de Ações para o Meio Ambiente. Como conseqüência destes fatos, foi instituído formalmente pela ONU, em 15 de dezembro de 1972, pela Resolução n. 2.997, o Programa das Nações Unidas para o Meio Ambiente (UNEP). ${ }^{29}$

Em 1992, entre os dias 3 e 14 de junho, foi realizada no Rio de Janeiro, a Conferência das Nações Unidas sobre o Meio Ambiente e o Desenvolvimento, também conhecida como Cúpula da Terra ou simplesmente ECO-92. ${ }^{30}$

Nessa conferência foram aprovadas a Declaração do Rio sobre Meio Ambiente e Desenvolvimento, a Agenda 21, a Declaração de Princípios sobre o Consenso Global no Manejo, Conservação e Desenvolvimento Sustentável de Todos os Tipos de Florestas, a Convenção sobre a Mudança Climática e, finalmente, a Convenção sobre a Diversidade Biológica (CDB), aprovada no Brasil pelo Decreto legislativo n. 2, de 3 de fevereiro de $1994 .^{31}$

Deve-se salientar que, durante a assinatura da CDB, o Governo dos EUA recusou-se a aceitar o texto da $\mathrm{CDB}$ sobre os temas da propriedade intelectual, transferência de tecnologia e biotecnologia. ${ }^{32}$

Além disso, a Comissão das Comunidades Européias também manifestou preocupação em relação a interpretação oferecida à alguns dispositivos da CDB, principalmente o art. 15, que trata do acesso aos recursos genéticos; o art. 16, que trata do acesso e transferência de tecnologia; o art. 19, sobre a gestão da biotecnologia e distribuição dos seus benefícios e o art. 22, sobre a relação da CDB com outras convenções internacionais. ${ }^{33}$

São três os principais objetivos da CDB, nos termos do seu art. $1^{\text {o }}$ : a conservação da diversidade biológica, a utilização sustentável dos seus componentes e

\footnotetext{
${ }^{28}$ SILVA, Eugênio Costa e. Breves Considerações sobre o acesso a recursos genéticos e alguns assuntos correlatos. Revista da ABPI, Rio de Janeiro, n. 28, p. 40-52, maio/jun. 1997.

29 Id. Ibid.

30 Id. Ibid.

31 Id. Ibid., p. 41-2.

32 Id. Ibid., p. 42.

33 Id. Ibid., p. 43.
} 
a repartição justa e equitativa, entre os países fornecedores da biodiversidade e os que a utilizarão, dos benefícios oriundos dessa utilização dos recursos genéticos contidos na biodiversidade. ${ }^{34}$

A CDB reconhece a soberania dos Estados sobre os seus recursos naturais, assim como, a autoridade dos mesmos para determinar o acesso aos seus recursos genéticos (art.15.1).

Determina ainda, que o acesso aos recursos genéticos, quando concedido, deverá sê-lo de comum acordo e sujeito ao consentimento prévio fundamentado da parte provedora desses recursos (art.15.4 e 5), e que cada país-membro deve adotar as medidas legislativas, administrativas e políticas, para garantir a distribuição justa e equitativa, entre o país que utiliza tais recursos e o que os fornece, dos resultados de pesquisa e desenvolvimento de recursos genéticos e dos benefícios derivados de sua utilização comercial (art.15.7).

Isto inclui a tecnologia, desenvolvida a partir desses recursos genéticos, protegida por patentes e outros direitos de propriedade intelectual (art.16.2), sendo que os países, reconhecendo que esses direitos podem influir na implementação da CDB, devem cooperar a esse respeito em conformidade com a legislação internacional e o Direito Internacional para garantir que esses direitos apóiem e não se oponham aos objetivos da CDB (art.16.5).

Logo, os países signatários da CDB e do TRIPS, pelo fato deste tratar dos aspectos comerciais das patentes e outros direitos de propriedade intelectual, têm o dever de alterar o texto do TRIPS, quando necessário, para que se harmonize com a CDB.

Em relação aos direitos das comunidades tradicionais (locais e indígenas) relativos ao seus conhecimentos quanto ao uso da biodiversidade, surgem algumas questões. Tradicionalmente, o conceito de propriedade intelectual inclui os direitos do Autor, marcas e inventos.

Contudo, o desenvolvimento de novas tecnologias ampliou consideravelmente esse conceito para passar a incluir o software, circuitos integrados, processos biotecnológicos e a partir da CDB pode-se incluir também esses conhecimentos das populações tradicionais, ${ }^{35}$ muitas vezes transmitidos exclusivamente de forma oral, sem registros escritos e sem um detentor individualizado, mas sim tendo por detentores uma comunidade inteira, pois este conhecimento está integrado à cultura dessa comunidade.

\footnotetext{
34 SILVA, Eugênio da Costa e. op. cit., p. 43.

35 SILVA, Eugênio da Costa e. Ciência, direitos intelectuais e biodiversidade. Revista da ABPI, Rio de Janeiro, n. 21, p. 3-6, mar./abr. 1996.
} 
$\mathrm{O}$ art.8, da $\mathrm{CDB}$, determina que:

em conformidade com sua legislação nacional, preservar e manter o conhecimento, inovações e práticas das comunidades locais e populações indígenas com estilo de vida tradicionais relevantesà conservação e à utilização sustentável da diversidade e incentivar sua mais ampla aplicação com a aprovação e a participação dos detentores deste conhecimento, inovações e práticas; e encorajar a repartição equitativa dos benefícios oriundos da utilização deste conhecimento, inovações e práticas.

Assim, estes conhecimentos deveriam ser passíveis de proteção dentro da esfera dos direitos de propriedade intelectual e, portanto, do TRIPS, o que infelizmente não ocorreu.

Um dos instrumentos jurídicos para uma possível implementação da CDB nos países-membros, seriam os contratos de prospecção de biodiversidade, desde que elaborados em consonância com as obrigações e direitos estipulados na CDB. ${ }^{36}$

Uma análise comparativa entre os dois diplomas internacionais revela que eles não se harmonizam de imediato, porque o TRIPS, apesar de posterior à CDB, não considerou as obrigações assumidas pelos países contratantes daquela convenção, no que tange à questão das patentes de recursos genéticos da biodiversidade ou de produtos que utilizassem estes recursos como matéria-prima.

Para tanto, seria necessário que o TRIPS, no que se refere à concessão de patentes de produtos e processos, reconhecesse e garantisse os direitos dos países provedores de recursos genéticos, provenientes da sua biodiversidade.

Cria-se assim, a princípio, a situação injusta e absurda de que muitos países, por força do TRIPS, teriam de reconhecer as patentes de recursos genéticos e seus derivados, provenientes de outros países, pagando por seu uso, ainda que esses recursos genéticos tivessem sua origem na biodiversidade daquele próprio país. ${ }^{37}$

O TRIPS, por outro lado, permite excluir da patenteabilidade invenções cuja exploração comercial em seu território devem ser impedidas para a proteção da ordem pública.

Logo, se um Estado-membro da CDB e TRIPS, aprova lei nacional em conformidade com os direitos e deveres determinados pela CDB, essa lei passa a ter caráter

\footnotetext{
${ }^{36}$ MAGAlHÃES, Vladimir G. Contratos de prospecção de biodiversidade: natureza jurídica. Revista do Instituto de Pesquisas e Estudos, Bauru, n. 16, p. 197-228, mar. 1997.

37 GRAF, Ana Cláudia B. Direito, Estado e economia globalizada: as patentes de biotecnologia e o risco de privatização da biodiversidade. Revista de Direito Ambiental, São Paulo, v. 5, n. 18, p. 153-162, 2000.
} 
de ordem pública no ordenamento jurídico daquele país podendo, portanto, afastar a patenteabilidade de alguns produtos ou processos, ainda que seja permitida pelo TRIPS.

Assim, se uma lei nacional que regulamente o acesso à biodiversidade e sua exploração comercial, determinar que não se reconheça naquele país a patente de produtos ou processos que firam de algum modo a $\mathrm{CDB}$, essa lei não estaria em desacordo com o TRIPS, por se enquadrar nesta faculdade de exclusão de patenteabilidade prevista no art. 27.2 do próprio TRIPS.

Por outro lado, os membros do TRIPS têm a faculdade de excluir também da patenteabilidade plantas e animais, mas não podem excluir a patenteabilidade de microorganismos e a proteção das variedades vegetais (art.27.3.b).

Mas, e se estes microorganismos e variedades vegetais forem provenientes ou derivados da biodiversidade daquele país, obtidos a partir dos recursos genéticos nela existentes e em desacordo com as obrigações impostas pela CDB?

Existiria, nesta hipótese, um conflito entre os dois diplomas internacionais. Em nosso entender a legislação nacional deveria condicionar o reconhecimento daquela patente, nos termos do TRIPS, ao cumprimento, ainda que a posteriori, das exigências impostas pela $\mathrm{CDB}$, como a repartição dos benefícios obtidos pela exploração daqueles recursos, através da patente pleiteada.

Por outro lado, o TRIPS não-discrimina se é possível patentear o gene natural isolado de plantas ou animais. Ocorre que, se é possível patentear-se isoladamente o conjunto de genes de um animal ou planta, se pode, em última análise, patentear aquele ser vivo, pois ele é expresso, exatamente, por esse conjunto dos seus genes, também chamado de genoma.

Assim, a princípio, pelo TRIPS, com a sua atual redação, estaríamos na absurda situação de que um país poderia patentear a biodiversidade de outro país. Outra questão, é a de que os microorganismos também fazem parte da biodiversidade. Assim, o TRIPS ao permitir o patenteamento destes seres, sem nenhuma exigência de observância dos requisitos de exploração da biodiversidade e seus recursos genéticos, previstos na $\mathrm{CDB}$, está gerando pontos de conflitos com esta convenção.

\section{Conclusão}

O texto do TRIPS deveria ser revisto para se harmonizar com a CDB, devendo incluir que as patentes obtidas, diretamente ou indiretamente, a partir da biodiversidade dos seus países, sem a devida autorização dos mesmos e sem a repartição dos benefícios 
de sua exploração científica e comercial, seriam automática e necessariamente excluídas do patenteamento em todos os países-membros.

A isto deveria se somar, como sanção, permitir aos países que tivessem seus direitos protegidos pela $\mathrm{CDB}$, feridos por outros países pelo patenteamento de produtos obtidos a partir de sua biodiversidade, que não reconhecessem, se quisessem, nenhum tipo de patente oriundas daqueles países infratores.

A revisão do texto do TRIPS, deveria incluir, ainda, como requisito de patenteabilidade, a comprovação de origem dos recursos genéticos utilizados para obtenção daquele produto ou processo, assim como a comprovação de obtenção destes recursos, de modo autorizado pela legislação nacional do país-provedor e o cumprimento da obrigação de repartir os benefícios comerciais e tecnológicos.

Além disso, o texto do TRIPS deveria ser revisto de modo a incluir, dentro dos direitos de propriedade intelectual, o conhecimento das populações tradicionais, para que estas tenham a reparticão dos benefícios deste conhecimento, garantido, nos termos do art. $8^{\circ}$, “j” da CDB.

O TRIPS deveria reconhecer e estabelecer um mecanismo eficiente para a proteção do conhecimento das populações tradicionais, escritos ou orais, os quais são passíveis de serem utilizados para a invenção de produtos ou processos, utilizando-se a biodiversidade a que este conhecimento tradicional está associado.

Finalmente, concluímos que esta harmonização entre o TRIPS e a CDB é imprescindível para que a utilização de acordos internacionais não fique desmoralizada como instrumento de convivência pacífica e eqüânime entre todos os países do planeta, pois o fato de um acordo firmado por um grupo de países não-facilitar o cumprimento de outro acordo, como ocorre com o TRIPS e a CDB, desmoraliza a prática, objetivos e fundamentos do Direito Internacional Público e da Diplomacia internacional e, além disso, caracteriza um sistema internacional de países hegemônicos e de países dominados politica e economicamente.

São Paulo, 17 de novembro de 2007.

\section{Referências}

BERLINGUER, Giovanni. Ciência, mercado e patentes do DNA humano. Bioética, Brasília, v.8, n. 1, p. 97-106, 2000. 
BERGEL, Salvador D. Patente de genes: implicâncias éticas e jurídicas. Bioética, Brasília, v. 5, n. 2, p. 243-252, 1997.

COSTA E SILVA, Eugênio Costa e. Breves considerações sobre o acesso a recursos genéticos e alguns assuntos correlatos. Revista da ABPI, Rio de Janeiro, n. 28, p. 41-51, 1997.

. Ciência, direitos intelectuais e biodiversidade. Revista da ABPI, Rio de Janeiro, n. 21, p. 3-6, 1996.

COUGHLIN, Michael D. Using the Merck-INBio agreement to clarify the convention on biological diversity. Columbia Journal of Transnational Law, New York, v. 31, n. 2, p. 337-375, 1993.

GRAF, Ana Cláudia B. Direito, Estado e economia globalizada: as patentes de biotecnologia e o risco de privatização da biodiversidade. Revista de Direito Ambiental, São Paulo, n. 18, p. 153-162, 2000.

DOBSON, Andrew P. Conservation and biodiversity. New York: Scientific American Library, 1996.

MAGALHÃES, Vladimir G. Contratos de prospecção de biodiversidade: natureza jurídica. Revista do Instituto de Pesquisas e Estudos-Divisão Jurídica, Bauru, n. 16, p. 197-228, mar. 1997.

OMPI, Intellectual Property Handbook: policy, law and use. Disponível em: <www.http.wipo.int/ about-ip/en/iprm>. Acesso em: 13 jun. 2002.

RAYOL, Alice. Biotecnologia, ética e patentes. Revista da ABPI, Rio de Janeiro, n. 44, p. 20-4, 2000 .

REAKA-KUDLA, Marjorie L.; WILSON, Don E.; WILSON, Edward O. (Eds.). Biodiversity II: understanding and protecting our biological resources. Washington, D.C.: Joseph Henry Press, 1997.

REID, Walter V. et al. Prospección da la biodiversidad. San José: Ed. INBio, 1994.

SILVA, Carlos E. da. EUA patenteiam vírus de índio e são acusados de pirataria. Folha de São Paulo, 16 de junho de 1996.

SOARES, José Carlos T. Biotecnologia: a mais avançada tecnologia da vida. Revista da ABPI, Rio de Janeiro, n. 10, p. 38-40, 1994.

STRYER, Lubert. Bioquímica. Rio de Janeiro: Editora Reverté, 1979.

WOLFF, Maria Teresa. Proteção do meio ambiente. Revista da ABPI, Rio de Janeiro, n. 16, p. 3033, 1995. 